DOI: $10.17516 / 1997-1370-0676$

УДК $339.9+338.49$

\title{
The State Border between China and Russia: Permeability and Barriers for International Cooperation
}

\author{
Anna B. Bardal** \\ Economic Research Institute FEB RAS \\ Khabarovsk, Russian Federation
}

Received 17.07.2020, received in revised form 11.09.2020, accepted 06.11.2020

\begin{abstract}
The length of the state border between China and Russia within the territory of the Far East Federal District is more than 4 thousand $\mathrm{km}$. The border has various functions. The contact function of the border is to stimulate economic interactions between countries. The border regions of the two countries benefit from international trade. The contact function is characterised by the permeability of the border. The barrier function of the border is to limit interactions between countries. Restrictions on the free movement of goods, labour resources, tourist flows, and capital are applied. The purpose of the study is to assess the elements of the contact function of the state border between China and Russia. The subject is functioning of the border in the Far East Federal District. The study used methods of economic geography and regional economics. As a result, the indicators of the border permeability between the Russian Far East and China (physical permeability, the density of cross-border infrastructure) were calculated. The characteristics of institutional conditions, such as the speed of customs clearance and the use of digital technologies in paperwork are presented. The conclusion about the low permeability of the border between China and Russia in the territory of the Far East Federal District is made. The directions for increasing the contact function of the border are formulated. The research results can be used to develop directions for the improvement of cross-border relations between Russia and China.
\end{abstract}

Keywords: China, Russian Far East, state border, permeability of the border, border barrier function.

Research area: economy.

Citation: Bardal, A.B. (2020). The state border between China and Russia: permeability and barriers for international cooperation. J. Sib. Fed. Univ. Humanit. Soc. Sci., 13(11), 1700-1709. DOI: 10.17516/19971370-0676.

\footnotetext{
(C) Siberian Federal University. All rights reserved

* Corresponding author E-mail address: Bardal@ecrin.ru ORCID: 0000-0002-9944-4714
} 


\section{Introduction}

A number of publications are devoted to the study of the development features of border regions. The authors consider issues of cross-border cooperation, a variety of institutions and economic effects. Some studies analyse the impact of competing rivals and border effects on the market potential formulation (Salas-Olmedo et al., 2015; Dorry, Decoville, 2016; Matas et al., 2015). Another work (Newman, 2006) presents a new stage in the study of the functions of boundaries and the complexity of their study using a multidisciplinary approach. Borders are regarded as a political, geographical, economic, cultural, etc. phenomenon. It is important to ensure security of a state.

A separate direction is represented by works devoted to the study of the features of economic development in the border regions. Some authors (Jacobs-Crisionia, Koomen, 2017) investigate connection between cross-border transport interaction for improving the market access and population growth for municipalities in ten countries in West Europe. They say that the barriers that borders impose are to be explained from institutional factors, as well as cultural and linguistic differences. The study (Rietveld, 2012; Niebuhr, Stiller, 2002) explores borders in terms of the spatial effects of integrating border regions. The authors conclude that the result in each case will be different. Depending on specific circumstances, border regions might benefit, lose or not be affected by integration.

Some works (Medeiros, 2019; Paasi, 2009; Pratt, Brown, 2000) discuss social processes in related regions of countries. These works analyse the consequences of different modes in relation to the construction of the barrier function of borders. The processes of cross-border migration and their impact on labor markets and tourism are considered (Schiebel et al., 2015; Huber, 2013; Gerber, 2012).

Numerous works are devoted to the study of changes in the barrier and contact functions of borders (Sohn, 2014; Wilson, Donnan, 2012). In trade models, national borders are tariff or non-tariff barriers to trade. The main result of traditional and recent trade models is that by reducing trade barriers integration increases international trade, which affects the international model of specialisation in production. The related economic adjustments are due to the redistribution of factors of production between sectors within the country. Factors of production are generally considered to be completely mobile in countries and between sectors, while they are completely immobile on an international scale. Thus, countries have fixed factors, and trade serves as a substitute for mobility factors. In addition, transport costs do not exist either at national or international levels. Therefore, each country is effectively treated as one geographic location.

The purpose of the study is to assess the elements of the barrier and contact functions of the state border between China and Russia. An analysis of the function of borders in this territory is important, since Russia can become one of the participants in the "One Belt and One Road" (OBOR) Initiative". The OBOR Initiative, first defined in 2013 by the President of China Xi Jinping, is the largest initiative to enhance global connectivity. However, not only cooperation at the global level, but also interaction of the regions are important.

A number of scientific publications have been devoted to various aspects of the OBOR project (Yau, Wang, 2018; Liu et al., 2018; Ge et al., 2020; Foo et al., 2019). The institutional foundations of the project, the possibilities of developing the transport network, and the economic effects for the countries involved in the project are considered.

The official document "Vision and Action on Jointly Building Silk Road Economic Belt and $21^{\text {st }}$ Century Maritime Silk Road" includes a description of global challenges and a section about regional cooperation. It contains a direct indication that it is necessary "to improve railway access and the regional railway network, allowing connecting Heilongjiang province and Russia, as well as cooperation in the field of combined land and sea transportation with the provinces of Heilongjiang, Jilin, Liaoning and the Russian Far East" (Vision..., 2015).

\footnotetext{
The initial name of the initiative is the Silk Road Economic Belt.
} 
This means that the "One Belt and One Road" initiative can conditionally single out goals at global and regional levels. The goals of the global level suggest the development of trade, economic and transport links between China and Europe in three main directions:

1) through Central Asia, Russia to Europe (to the Baltic Sea);

2) through Central and Western Asia to the Persian Gulf and the Mediterranean Sea;

3) to Southeast and South Asia to the Indian Ocean.

It encompasses 65 countries with more than a half of the world's population, $40 \%$ of the world GDP, and could cost more than one trillion dollars to build.

These areas will be supported by the development of infrastructure along the following corridors. The Silk Road Economic Belt is a long-term vision for the infrastructural development, connectivity and economic cooperation of Eurasia and is spanning six development "corridors", namely:

1. New Eurasian Land Bridge Economic Corridor.

2. China - Mongolia - Russia Economic Corridor.

3. China - Central Asia - West Asia Economic Corridor.

4. China - Indochina Peninsula Economic Corridor.

5. Bangladesh - China - India - Myanmar Economic Corridor.

6. China - Pakistan Economic Corridor.

For maritime transport, the initiative involves the development of routes from the coastal ports of China through the South China Sea to the Indian Ocean and further to Europe, as well as to the southern Pacific Ocean. These directions are included in the project "The $21^{\text {st }}$ Century Maritime Silk Road". In addition, in 2018, the "Polar Silk Road" project, that was also included into the OBOR initiative, was presented.

The objectives of the regional level of the Project imply the development of interactions between the regions (administrative entities) of the Russian Federation in the Far East and the neighboring provinces of the PRC. Allocation of the regional level can be regarded only from the point of view of resolving the local development problems of the northeastern provinces of China and the border regions of Russia that are not related to the global goals of the OBOR project (Bardal, 2016).

For the development of interactions, the transport connectivity of the border territories of the two countries at the regional level is important. Connectivity is about more than transport infrastructure. EU High Representative, Federica Mogherini, defines it as "the physical and non-physical infrastructure through which goods, services, ideas and people can flow unhindered" (Russell, 2019). It is as much about non-material (soft) aspects (customs procedures; legislative frameworks; technical standards, etc.) as about 'hard' physical infrastructure, such as new railways and energy pipelines. In a globalised economy, countries are connected by transport, energy and digital networks, as well as people-to-people contacts, all of which are increasingly essential for economic prosperity and sustainable development.

At the same time, the contact and barrier functions of state borders become important. Contact functions are reflected at the level of permeability of borders. The barrier functions of borders affect the scale of economic interactions. Reducing the limiting effect of borders leads to the expansion of economic interactions, the formation of a common market space in the framework of regional agreements of various types. According to the logic of many researchers, this should have a significant impact on the spatial and economic development of bordering countries and regions. A decrease in the barrier functions of borders leads to an increase in the cohesion of border areas.

This article attempts to assess the connectedness (i.e. boundary permeability) of the Northeastern provinces of the PRC and the regions of the Russian Federation in the Far East from the point of view of the possibilities of implementing the regional level of the "One Belt and One Road" Initiative.

We can note the lack of work on the barrier and contact functions of borders in relations between Russia and China in the Far East. Given the prospects for the implementation of the 
project "One Belt and One Road", this is an important and relevant issue at the present stage.

\section{Research methods}

The Russian Far East is a border region. Within its vast land territory (6.9 million square kilometers) and the sea area, there are sections of the state border with the PRC, DPRK, the United States and Japan. The length of the border with China is more than 4 thousand $\mathrm{km}$, including land ( $16 \%$ of the total length), river ( $83 \%$ of the total length) and lake $(1 \%$ of the total length) sections. The potential for international cooperation between the region and China is high.

The intensification of interactions between countries requires the availability of sufficient scale and quality infrastructure, including transport, border and customs. Currently, between the North-Eastern provinces of China and the border regions of the Far East of the Russian Federation, traffic is carried out along road (more than 30) and three railway transport directions. There are prospects for the integration of transport systems of two neighboring countries (Bardal, 2019).

The number of checkpoints on the state border with time varies with the needs of the economy. So, in the autumn of 2011 in the Amur Oblast a mixed cargo-passenger checkpoint of Skovorodino was established. This point was organised to service "The Russian Eastern Siberia - Pacific Ocean" oil pipeline branch of the Russian oil pipeline to China. The operational crews pass customs and border control here; its validity period is limited by the agreement of the Russian Federation and China on cooperation in the oil sector and is 23 years.

Some officially established border-crossing checkpoints are currently not functioning due to the lack of cargo and passenger traffic. So, the Kani-Kurgan - Changfatun checkpoint, established in 1996 in the area of the proposed construction of a bridge across the Amur River in the area of Blagoveshchensk. The transition was organised as temporary to ensure the movement of personnel involved in construction, building materials, equipment and machinery. However, this project has not been implemented. The checkpoints of Jalinda-Mo- he and Konstantinovka-Sunu were organised taking into account possible prospects, however, transportation to these directions is not currently carried out.

In our opinion, two components are important in studying the role of borders in economic interactions between China and the Russian Federation: 1) the permeability of borders, 2) the barrier nature of borders.

The physical permeability of borders, if understood as the potential for crossing the border, is determined by the presence of transport communications on this section (roads and railways), or the presence of navigable sections of rivers (Sokolov, 2017).

The barrier of borders is understood as the presence of organisational, economic and institutional obstacles or their absence when crossing a border between countries (Kolosov et al., 2016a). These are important factors determining the complexity of border crossing associated with the established regime of official services; time spent on paperwork; the number of services exercising control at the border and the duration of their work (border service, customs service, phytosanitary control, etc.); the possibility of using electronic forms of documents and so on.

In general, barrierness is a category that changes in time and space. It depends on the redistribution of the contact and barrier functions of the boundaries in a certain period. The barrier is largely determined by the direction of foreign policy and integration processes between specific countries.

Given the strategic prospects for the implementation of the "One Belt and One Road" project for the border regions of the Russian Far East and the provinces of China, it is very important to assess the barrier between the countries. It is also important to understand in which areas cooperation can be improved to be more effective for the benefit of our countries.

As a part of the analysis of border permeability, the adjusted formula for calculating border permeability $\left(C_{i j}\right)$ was used to evaluate interactions within one country. We have adjusted this formula taking into account the peculiarities of the situation under consideration: 
analysis of the permeability of external borders between countries $i$ (PRC) and $j$ (Russia):

$$
C_{i j}=\frac{10}{l_{i j}}\left(2 q_{i j}+0.5 a_{i j}+0.1 k_{i j}+0.2 v_{i j}\right),
$$

where $l_{i j}$ - is the length of the border between the countries $\mathrm{i}$ and $\mathrm{j}$ under consideration; $q_{i j}-$ the number of border crossings between the territories under consideration by railways, $a_{i j}$ - the number of border crossings between the territories under consideration by paved roads, $k_{i j}$ - is the number of border crossings between the territories under consideration by roads with a transitional type of coating (unpaved), $v_{i j}$ - is the number of border crossings between the territories under consideration by waterways with shipping potential.

The adjustment affected, firstly, the division of roads into two types: with a hard coating and with a transitional type of coating, as these roads have different quality of pavement and can be used for transportation of cargo flows of various scales. The feature of the Sino-Russian border in the Far East is that there are many river masses on the border.

Secondly, when calculating permeability, only rivers with shipping potential, i.e. possessing the depths and width necessary for shipping, were taken into account. The inclusion of all rivers crossing the borders in the calculation will not make it possible to correctly assess the development potential of transport links.

We have adopted the weights for individual modes of transport based on the current structure of freight transportation in the region at the end of 2019 (in terms of the volume of the goods transported).

The introduced changes distinguish the formula used later for calculations from that one previously proposed by other authors (Privalovskaya et al., 1995; Sokolov, 2017).

The initial data necessary for the calculations are not available in the sources of official statistics of Rosstat. Therefore, the required primary data on the length of the borders were collected by the author independently using the Google Maps online mapping tools. Assessment of the potential possibilities of the navigating conditions of the rivers was made on the basis of the data from the administrations of the Amur and Lensky basins of inland waterways.

The following indicators were used in the study: the length of sections of the state border within individual subjects of the Far East $(\mathrm{km})$, the number of intersections of sections of the state border of the Russian Federation in the Far East by railways (units), the number of intersections of sections of the state border of the Russian Federation in the Far East by road with hard coating (units), the number of crossings of sections of the state border of the Russian Federation in the Far East by roads with transitional type coating (units), the number of crossings of sections of the state border of the Russian Federation in the Far East by rivers with the potential for shipping conditions (units), volumes of transport by mode of transport (million tons).

The barrier function of state borders can be estimated by the following parameters (Kolosov et al., 2016b):

- the number of checkpoints (automobile, railway, river, mixed), their type (bilateral, multilateral), the density of checkpoints per $1000 \mathrm{~km}$ of the border, their capacity and mode of operation;

- infrastructural restrictions (differences in railway gauge, the need to change wheelsets);

- border crossing regime for individuals and consignments (the presence of a visa regime, the complexity of applying for a visa, the complexity of processing freight documents);

- existing agreements on border crossing between states (simplified border crossing regime, special regime for residents of border regions);

- real cross-border flows (individuals, freight transportation);

- measures to facilitate border crossing (the possibility of pre-booking a place in the queue at the border inspection, the possibility of preliminary electronic declaration of carriage, the possibility of electronic documents submission).

It should be noted that the sources of open official statistical information do not contain the above indicators. However, the necessary indicators can be obtained from the open data sources: the portal of the Ministry of Transport 
of the Russian Federation (to which the functions of the Federal Agency for the Development of the State Border of the Russian Federation have been transferred since 2018), and the Far Eastern Customs Directorate directly from the regional customs service. And also, as a result of personal observation of the work of checkpoints on the state border between the Russian Federation and China, as well as in scientific publications on this issue.

\section{Results}

The intensification of cooperation between Russia and the PRC acquired new aspects after the proclamation of the "One Belt and One Road" Initiative in 2013 by the President Xi Jinping. For the regions of the Russian Far East, additional opportunities have appeared for the development of joint actions with the border north-eastern provinces of China. The successful development of such cooperation can be facilitated by an increase in the permeability of state borders and a decrease in their barrier functions.

Table 1 shows the estimates of the permeability of the border between the Russian Federation and China in the Far East.

The obtained indicators are determined by the prevailing economic and natural-geographical conditions. They characterise physical ability to cross the state border for the population and goods. The obtained permeability indices are rather low in comparison with the permeability of the external borders of the western regions of Russia. Assessments indicate the insufficient use of the potential for cooperation between the border territories of the two countries.

Considering the barrier between the PRC and the Russian Federation for clarity, we summarise the main indicators in Table 2.

When carrying out rail transportation between China and the Russian Federation, the question of infrastructure incompatibility arises. In China, the railway gauge is $1435 \mathrm{~mm}$, in Russia $-1520 \mathrm{~mm}$. This leads to loss of time during transportation of goods in connection with the need to replace wheel sets or overload.

However, cross-border transport infrastructure between China and the Russian Federation is developing. Currently, the construction of two bridge crossings is nearly completed.

1. In 2016, the construction of an automobile bridge between Blagoveshchensk (Amur Oblast) and Heihe (Heilongjiang Province) started. A joint Russian-Chinese bridge operator, which received a loan from the Heilongjiang Provincial Government Bank with an interest rate of 5\% per annum, was created. The total project cost is estimated at 18.8 billion rubles.

The length of the main bridge across the main channel of the Amur River will be 1.1

Table 1. Characteristics of the permeability of borders between China and the Russian Federation within the territory of the Far East

\begin{tabular}{|c|c|c|c|c|c|}
\hline \multirow{2}{*}{ Territory } & \multirow{2}{*}{$\begin{array}{l}\text { The length of } \\
\text { the state border } \\
\text { with China, km }\end{array}$} & \multicolumn{3}{|c|}{ The number of border crossings, units } & \multirow{2}{*}{$\begin{array}{l}\text { Permeability } \\
\text { rate }\end{array}$} \\
\hline & & by rail & by $\operatorname{road} *$ & by river $* *$ & \\
\hline $\begin{array}{l}\text { Far Eastern Federal District } \\
\text { as a whole }\end{array}$ & 4182 & 3 & 12 & 71 & 0.063 \\
\hline Primorsky Krai & 1032 & 2 & 5 & 28 & 0.117 \\
\hline Khabarovsk Krai & 260 & 0 & 0 & 33 & 0.254 \\
\hline Amur Oblast & 1312 & 0 & 0 & 4 & 0.006 \\
\hline Jewish Autonomous Oblast & 514 & 0 & 0 & 2 & 0.008 \\
\hline Trans-Baikal Krai & 1064 & 1 & 7 & 4 & 0.059 \\
\hline
\end{tabular}

Source: calculated by the author.

Note: ${ }^{*}$ - within the limits of one automobile checkpoint several automobile roads may operate;

** - the correct calculation of this indicator is complicated by the fact that most of the state border between the PRC and the Russian Federation within the Far East goes along the large rivers the Amur and Argun. 
Table 2. Characteristics of checkpoints across the state border between China and the Russian Federation within the territory of the Far East*

\begin{tabular}{|l|c|c|c|c|c|}
\hline \multicolumn{1}{|c|}{ Indicators } & $\begin{array}{c}\text { Primorsky } \\
\text { Krai }\end{array}$ & $\begin{array}{c}\text { Khabarovsk } \\
\text { Krai }\end{array}$ & Amur Oblast & $\begin{array}{c}\text { Jewish } \\
\text { Autonomous } \\
\text { Oblast }\end{array}$ & $\begin{array}{c}\text { Trans-Baikal } \\
\text { Krai }\end{array}$ \\
\hline $\begin{array}{l}\text { The number of checkpoints, } \\
\text { total units }\end{array}$ & $7 / 7$ & $3 / 2$ & $9 / 4$ & $4 / 3$ & $6 / 4$ \\
\hline - railway checkpoints & $2 / 2$ & $0 / 0$ & $0 / 0$ & $1 / 1$ & $1 / 1$ \\
\hline - car checkpoints & $5 / 5$ & $1 / 0$ & $1 / 0$ & $0 / 0$ & $5 / 3$ \\
\hline - river checkpoints & $0 / 0$ & $1 / 1$ & $0 / 0$ & $0 / 0$ & $0 / 0$ \\
\hline - mixed checkpoints** & $0 / 0$ & $1 / 1$ & $7 / 4$ & $3 / 2$ & $0 / 0$ \\
\hline - pedestrian checkpoints & $0 / 0$ & $0 / 0$ & $1 / 0$ & $0 / 0$ & $0 / 0$ \\
\hline $\begin{array}{l}\text { Density of operating check- } \\
\text { points per 1 thousand km of } \\
\text { border, units }\end{array}$ & 6.78 & 7.69 & 3.05 & 5.84 & 3.76 \\
\hline
\end{tabular}

Source: calculated by the author using data from Rosgranitsa.

Note: ${ }^{*}$ - number of formally established / actually operating checkpoints;

** - in summer, transportation is carried out by river transport, in winter season transportation is carried out by cars on frozen rivers.

$\mathrm{km}$. A bridge over the Kani-Kurgan canal, on the approaches to the federal highway "Access to Blagoveshchensk" on the Russian side will also be erected. The construction of the bridge is carried out simultaneously on the Russian and Chinese sides. In 2019, construction was completed. In 2020, after technical documentation is completed, the bridge will be commissioned.

Experts from China intend to create a free trade zone with special tax and customs regimes near the bridge. It is also planned to build a cableway across the Amur River and a passenger terminal with a capacity of 2.5 million people a year near the bridge.

2. In 2008, an agreement on the construction of a railway bridge across the Amur was concluded $(2.18 \mathrm{~km}$ long, combined track of $1520 \mathrm{~mm}$ and $1435 \mathrm{~mm}$ ). This bridge will connect Nizhneleninsky (Jewish Autonomous Okrug) and the city of Tongjiang (Heilongjiang province). In 2013, an intergovernmental agreement on the construction of a cross-border railway bridge Nizhneleninskoye-Tongjiang was signed. In 2014, the "Petropavlovsk Group", the main investor, withdrew from the project. In June 2016, the construction company "Most" started working on the bridge construction (the length of the Russian part is 309 meters).
In China, the bridge will join the Xiangyuan-Haiyudao railway line, and in Russia, the Trans-Siberian Railway. The bridge is primarily intended for the transportation of iron ore concentrate of the Kimkano-Sutarsky mining and processing plant (started operating in 2015). The volume of transported goods will initially amount up to 12 million tons and may increase to 33 million tons in the future. In 2019, the bridge was docked. The completion and start of operation is planned at the end of 2020.

The bridge construction that is worth more than 10.5 billion rubles is financed from several sources: the Russia-China Investment Fund (the main part), created by the Russian Direct Investment Fund and China Investment Corporation, as well as the Far East Development Fund.

The railway bridge is a link in ensuring transport accessibility of the mining and metallurgical cluster being created in the territory of the Jewish Autonomous Okrug, which, in addition to the Kimkano-Sutarsky mining and processing plant, includes the Garinsky mining and processing plant, as well as the metallurgical complex in the Kimkano-Sutarsky district (planned capacity of 2.5 million tons per year of iron by direct reduction method). 
To implement the project in full extent, in addition to the construction of the bridge, the reconstruction of the inactive Birobidzhan-Leninskoye railway line $(120 \mathrm{~km})$, its electrification, as well as the construction of a new line from the Garinsky mining and processing plant to the Trans-Siberian Railway are necessary.

However, the development of cross-border infrastructure is proceeding at a slow pace. In conditions of insufficiently developed infrastructure (including transport), the stimulating function of the state border cannot be fully manifested. It will be difficult for countries to realise the prospects of the "One Belt and One Road" Initiative.

The contact function of borders also depends on the institutional conditions to which the border crossing regime is applied. The border crossing regime between the Russian Federation and the PRC is being simplified. For example, in the special territories of the Free Port of Vladivostok, since 2017, a visa-free regime has been in effect for the entry of citizens of 18 states, including the PRC. An electronic visa is issued free of charge for up to 8 days. Business, tourist, and humanitarian visas are issued. The territory of the Free Port includes all the main seaports in the south of the Far East, as well as the airport in Vladivostok.

Registration of the flow of goods takes place using electronic paperwork and a preliminary declaration procedure. Within the Free Port of Vladivostok, sea and rail checkpoints operate around the clock and seven days a week. This allows to speed up the procedure for inspection and border crossing.

\section{Conclusions and discussion}

Currently, the permeability of borders between China and the Russian Federation in the Far East is low. The potential geographic location of the two countries (significant development of river systems) is not used to the full extent. At the same time, the insufficient development of transport infrastructure, the difference in track gauge, low density of checkpoints, etc., determine the high barrier to the border between China and the Russian Federation.

Weak permeability of the state border along with a high barrier function may become a limiting factor in international cooperation in the future. The development of cooperation in the framework of the "One Belt and One Road" Initiative contributes to an increase in economic ties. This means that it is necessary to actively develop the transport infrastructure of the border regions of the PRC and the Russian Federation, build new railways, roads and bridges, as well as open new checkpoints.

Further development of research in this direction may be related to the refinement of the data used in the work, the assessment of additional parameters of border barrier, the development of options for increasing the permeability of borders, and the assessment of the relationship of permeability with the economic development of the region.

\section{References}

Bardal, A.B. (2016). Novyi Shelkovyi Put': vozmozhnosti i ugrozy dlia transportnogo kompleksa Dal'nego Vostoka Rossii [The New Silk Road: Opportunities and Threats for the Transport Complex of the Russian Far East]. In JeKO [ECO], 7 (505), 69-80.

Bardal, A.B. (2019). Potentsial integratsii transportnogo kompleksa vostoka Rossii v mezhdunarodnyi rynok transportnykh uslug [The Potential for Integration of The Transport Complex of the East of Russia into The International Market of Transport Services]. In Ekonomicheskie $i$ sotsial'nye peremeny: fakty, tendentsii, prognoz [Economic and Social Changes: Facts, Trends, Forecast], 12 (6), 150-165. DOI: 10.15838/esc.2019.6.66.8

Belt and Road Initiative (2020). Available at: https://www.beltroad-initiative.com/belt-and-road/ (accessed 18 March 2020).

Dorry, S., Decoville, A. (2016). Governance and transportation policy networks in the cross-border metropolitan region of Luxembourg: A social network analysis, In European Urban and Regional Studies, 23 (1), 69-85. DOI: 10.1177/0969776413490528 
Jacobs-Crisionia, C., Koomen, E. (2017). Population Growth, Accessibility Spillovers and Persistent Borders: Historical Growth in West-European Municipalities. In Journal of Transport Geography, 62, 8091. DOI: 10.1016/j.jtrangeo.2017.05.008

Foo, N., Lean, H.H., \& Salim, R. (2019). The impact of China's one belt one road initiative on international trade in the ASEAN region. In The North American Journal of Economics and Finance, 11, 101089 (In Press). DOI: https://doi.org/10.1016/j.najef.2019.101089

Ge, Y., Dollar, D., \& Yu, X. (2020). Institutions and participation in global value chains: Evidence from belt and road initiative. In China Economic Review, 61, 101447. DOI: 10.1016/j.chieco.2020.101447

Gerber, P. (2012). Advancement in conceptualizing cross-border daily mobility: The Benelux context in the European union. In European Journal of Transport and Infrastructure Research, 12 (2), 178-197. DOI: 10.18757/ejtir.2012.12.3.2980

Huber, P., Nowotny, K. (2013). Moving across Borders: Who is Willing to Migrate or to Commute? In Regional Studies, 47 (9), 1462-1481. DOI: 10.1080/00343404.2011.624509

Kolosov, V., Zotova, M., \& Sebentsov, A. (2016a). Bar'ernaia funktsiia rossiiskikh granits [Barrier Function of Russian Borders]. In Izvestiia Rossiiskoi akademii nauk. Seriia geograficheskaia [Proceedings of the Russian Academy of Sciences. Geographical Series], 5, 8-20.

Kolosov, V., Zotova, M., \& Sebentsov, A. (2016b). Podkhody k otsenke bar'ernosti rossiiskikh granic. Rossiiskoe pogranich'e: social'no-politicheskie i infrastrukturnye problemy [Approaches to Assessment of a Barrier of the Russian Borders. Russian Border Zone: Socio-Political and Infrastructure Problems]. In Rossiiskoe pogranich'e: social'no-politicheskie i infrastrukturnye problemy [Russian Border Zone: Socio-Political and Infrastructure Problems], 26-43.

Liu, X., Zhang, K., Chen, B., Zhou, J., Miao, L. (2018). Analysis of logistics service supply chain for the One Belt and One Road initiative of China. In Transportation Research Part E: Logistics and Transportation Review, 117, 23-39. DOI: 10.1016/j.tre.2018.01.019

Matas, A., Raymond, J.-L., \& Roig, J.-L. (2015). Wages and Accessibility: The Impact of Transport Infrastructure. In Regional Studies, 49 (7), 1236-1254. DOI: 10.1080/00343404.2013.827336

Medeiros, E. (2019). Cross-border transports and cross-border mobility in EU border regions. In Case Studies on Transport Policy, 7 (1), 1-12. DOI: 10.1016/j.cstp.2018.11.001

Newman, D. (2006). Borders and Bordering Towards an Interdisciplinary Dialogue. In European Journal of Social Theory, 9 (2), 171-186. DOI: 10.1177/1368431006063331

Niebuhr, A., Stiller, S. (2002). Integration Effects in Border Regions: A Survey of Economic Theory and Empirical Studies. Hamburg, Hamburg Institute of International Economics, 179 p.

Paasi, A. (2009). Bounded Spaces in a 'Borderless World': Border Studies, Power and The Anatomy of Territory. In Journal of Power, 2 (2), 213-234. DOI: 10.1080/17540290903064275

Pratt, M., Brown, J. (2000). Borderlands under Stress. Amsterdam, Kluwer Law International, 480.

Privalovskaya, G., Tarkhov, S., \& Treyvish, A. (1995). Territorial'naia struktura hoziaistva staroosvoennykh raionov [Territorial Structure of Economy of The Old Developed Areas]. Moscow, Nauka, $181 \mathrm{p}$.

Russell, M. Connectivity in Central Asia (2019). Available at: https://www.europarl.europa.eu/RegData/etudes/BRIE/2019/637891/EPRS_BRI(2019)637891_EN.pdf (accessed 20 March 2020).

Rietveld, P. (2012). Barrier effects of borders: Implications for border-crossing infrastructures. In European Journal of Transport and Infrastructure Research, 12 (2), 150-166. DOI: 10.18757/ejtir.2012.12.2.2959

Salas-Olmedo, M., García, P. \& Gutierrez, J. (2015). Accessibility and Transport Infrastructure Improvement Assessment: The role of Borders and Multilateral Resistance. In Transportation Research Part A: Policy and Practice, 82, 110-129. DOI: doi.org/10.1016/j.tra.2015.09.009

Schiebel, J., Omrani, H., \& Gerber, P. (2015). Border effects on the travel mode choice of resident and crossborder workers in Luxembourg. In European Journal of Transport and Infrastructure Research, 15 (4), 570-596. DOI: 10.18757/ejtir.2015.15.4.3098

Sohn, C. (2014). Modelling Cross-Border Integration: The Role of Borders as a Resource. In Geopolitics, 19 (3), 587-608. DOI: 10.1080/14650045.2014.913029 
Sokolov, S. (2017). Pronitsaemost' granits kak pokazatel' transportno-geograficheskogo polozheniia [Permeability of Borders as An Indicator of The Transport-Geographical Position]. In Mezhdunarodnyi forum po neskol'kim akademicheskim distsiplinam [An International Forum for Multiple Academic Disciplines], 31-40.

Vision and Action on Jointly Building Silk Road Economic Belt and $21^{\text {st }}$ Century Maritime Silk Road (2015). Available at: http://ru.china-embassy.org/rus/ggl/t1257296.htm (accessed 18 March 2020).

Wilson, T.M., Donnan, H. (2012). A Companion to Border Studies. London, John Wiley and Sons, 620. DOI: $10.1002 / 9781118255223$

Yau, S., Wang, J.J. (2018). Case studies on transport infrastructure projects in belt and road initiative: An actor network theory perspective. In Journal of Transport Geography, 71, 213-223. DOI: 10.1016/j. jtrangeo.2018.01.007

\title{
Российско-китайская граница: проницаемость и барьерность для международных взаимодействий
}

\author{
А.Б. Бардаль \\ Институт экономических исследований ДВО РАН \\ Российская Федеращия, Хабаровск
}

\begin{abstract}
Аннотация. В пределах территории Дальнего Востока протяженность границы между РФ и КНР составляет более 4 тыс. км. Государственная граница может выполнять контактные и барьерные функции. Контактная функция состоит в стимулировании экономических взаимодействий между странами. Приграничные регионы двух стран получают дополнительные выгоды от торговли, туристического обмена, реализации совместных проектов. Контактная функция характеризуется проницаемостью границы. Барьерная функция границы состоит в ограничении взаимодействий между странами. При этом применяются ограничения свободного перемешения товаров, трудовых ресурсов, туристических потоков, капиталов. Цель представляемого исследования - оценить элементы контактной функции границы между КНР и РФ на Дальнем Востоке. Предмет - функционирование границы между РФ и КНР. В работе используются методы экономической географии и региональной экономики. Для оценки контактной функции границы рассчитаны показатели проницаемости границы между Дальним Востоком России и КНР (физическая проницаемость, плотность таможенной и транспортной инфраструктуры). Представлены характеристики институциональных условий: скорость таможенного оформления, применение цифровых технологий при оформлении документов. В итоге сделан вывод о низкой проницаемости границы между РФ и КНР на Дальнем Востоке. Сформулированы направления повышения контактной функции границы при развитии инфраструктуры. Предложены направления дальнейших исследований. Результаты исследования могут быть использованы для разработки направлений развития приграничных взаимоотношений между РФ и КНР.
\end{abstract}

Ключевые слова: Китай, российский Дальний Восток, государственная граница, проницаемость границы, барьерная функция границы.

Научная специальность: 08.00.00 - экономические науки. 